\title{
Australia and Stateless Palestinians
}

\author{
SAVITRI TAYLOR
}

\section{Abstract}

This article considers Australia's treatment of stateless Palestinian asylum seekers and discusses whether that treatment discharges Australia's legal and/or moral obligations towards the individuals in question. The conclusion

drawn is that it does not.

\section{Résumé}

L'article prend en considération le traitement que l'Australie réserve aux demandeurs d'asile palestiniens apatrides et demande si ce traitement décharge l'Australie de ses obligations juridiques et/ou morales envers les individus en question. La conclusion établit qu'il n'en est rien.

\section{Introduction}

7 he primary function of the state is to protect its associated people (its nationals) from Hobbes's "war of all against all." Unfortunately, there are about nine million people worldwide who are in the situation of being "cast adrift from the global political system of nation states." ${ }^{1}$ These people are "not considered as a national by any State under the operation of its law" and hence are $d e$ jure stateless. ${ }^{2}$ Refugees, by contrast, may well possess the nationality of some country, but find themselves persecuted rather than protected in their country of nationality. ${ }^{3}$ Some stateless persons are unlucky enough to be refugees as well, meaning that they find themselves faced with persecution in their country of habitual residence.

In an earlier era than our own, not much distinction was drawn between stateless persons and refugees because what was considered significant was what they had in common - their lack of state protection. ${ }^{4}$ However, the trend since World War II has been that the international community has focused less and less on the fact that an individual lacks state protection and more and more on the reasons for the lack in determining whether or not to provide substitute protection. Those who lack state protection for reasons other than the reasons set out in the Convention Relating to the Status of Refugees (Refugee Convention) ${ }^{5}$ have found themselves increasingly marginalized. In particular, while there is a Convention Relating to the Status of Stateless Persons (Statelessness Convention) ${ }^{6}$ only 57 states $^{7}$ are parties to it compared to the 145 states $^{8}$ that are parties to the Refugee Convention and/or Refugee Protocol.

This article considers the plight of the approximately 3,723,036 Palestinians who are not formally nationals (citizens) of any country, ${ }^{9}$ i.e. are de jure stateless. It then considers the extent to which these individuals are able to rely for protection on the two treaty regimes specified above and on the more general body of international human rights law. The article next considers whether Australia's treatment of stateless Palestinians complies fully with all of its obligations under the Refugee Convention, the Statelessness Convention, and the general body of international human rights law and concludes that it does not. Finally, the article argues that Australia not only has international legal obligations towards stateless Palestinians but also moral obligations incurred through past action. It suggests that in order to discharge these moral obligations Australia should not only meet its strict legal obligations to stateless Palestinians but also give serious consideration to conferring its own nationality on stateless Palestinians in Australia who have nowhere else to turn.

\section{The Palestinians}

For as long as the three great monotheistic religions have been in existence, the territorial entity now described as Palestine has had a distinct identity derived from those religions. It is the Holy Land. ${ }^{10}$ The Jews settled Palestine about one thousand years before the birth of Christ. However, by the end of the seventh century most of the population of Palestine was Arab and Muslim and in 1516 it became part of the Ottoman Empire. ${ }^{11}$ From about 1882, Jews began migrating or returning (depending on your point of view) to the Holy Land. From about 1904-5, most of the migrants were angry young men and their goal was to make "Palestine become as Jewish as England is English."12 In other words, they were Zionists. 
At the time Jewish migration commenced, the Holy Land had a permanent population of about 462,000 persons. Most of these inhabitants were Arab Muslims, some were Arab Christians, and about 15,000 were Jews. ${ }^{13}$ By 1914, the population of Palestine had increased to over 720,000 of whom about 60,000 were Jews and the rest Arab. ${ }^{14}$

During World War I, the Ottoman Empire allied itself with Germany and in the course of the war Britain and France occupied its territories. Just before Armistice in 1918, those two countries announced that they intended "the complete and definitive liberation of the peoples so long oppressed by the Turks and the establishment of national Governments and Administrations drawing their authority from the initiative and free choice of the indigenous populations." 15 What they in fact did after World War I was to follow through on a secret plan to carve up former Ottoman territory between themselves. ${ }^{16}$ Palestine, Jordan and Iraq went to Britain. ${ }^{17}$

In place of straight out colonial rule, Britain and France had themselves appointed as League of Nations Mandatories of the territories they acquired during the war. Mandatories were given supervision and control of mandated territories, but not sovereignty over them. ${ }^{18}$ Article 22 of the Covenant of the League of Nations (the Covenant) provided:

To those colonies and territories which as a consequence of the late war have ceased to be under the sovereignty of the States which formerly governed them and which are inhabited by people not yet able to stand by themselves under the strenuous conditions of the modern world, there should be applied the principle that the wellbeing of such people form a sacred trust of civilization...

The best method of giving practical effect to this principle is that the tutelage of such peoples should be entrusted to advanced nations.... and that this tutelage should be exercised by them as Mandatories on behalf of the League. ${ }^{19}$

As David Abernethy points out, this "acknowledgement by colonial powers that they had a moral and legal responsibility to foster the well-being of colonized people on behalf of the larger international community was an important break from the past." 20 The Arab inhabitants of Palestine were unimpressed. They believed for a start that Britain had reneged on the promise of liberation made just before Armistice. Moreover, it was evident to them that the terms of the Palestine Mandate were geared not towards giving effect to the principles set out in Article 22 of the Covenant but rather towards giving effect to the Balfour Declaration of November 1917 in which Britain had supported "the estab- lishment in Palestine of a national home for the Jewish people." Article 22 of the Covenant stated:

Certain communities formerly belonging to the Turkish Empire have reached a stage of development where their existence as independent nations can be provisionally recognized subject to the rendering of administrative advice and assistance by a Mandatory until such time as they are able to stand alone.

Yet, as Omar Dajani points out,

in contrast to its numerous explicit commitments to the establishment of a "Jewish national home" in Palestine, the Mandate referred to the indigenous Arab population of the country, which in 1922 represented almost 90\% of Palestine's total population, primarily in contradistinction to the Jewish population. The Mandate, therefore, transformed the "independent nation" provisionally recognized by the Covenant into an assortment of "non-Jewish communities" that happened to reside within the borders of the territory of Palestine. ${ }^{21}$

Article 2 of the Palestine Mandate at least provided that in addition to "placing the country under such political, administrative and economic conditions as will secure the establishment of the Jewish national home," the Mandatory was responsible for "the development of self-governing institutions, and also for safeguarding the civil and religious rights of all the inhabitants of Palestine, irrespective of race and religion." 22 However, Britain did not in fact allow the Palestinians to develop self-governing institutions for fear that this would jeopardize the establishment of a Jewish homeland in Palestine. ${ }^{23}$ By contrast, during the mandate period, the Zionists managed to put in place a 'continuum of "Jewish territory"' and a parallel Jewish polity in Palestine. ${ }^{24}$

During the interwar period, 100,000 European Jews migrated to Palestine. Many were, of course, refugees fleeing the spread of Nazism. ${ }^{25}$ However, Arab Palestinians focused on their own dispossession and responded to Jewish settlement with an armed uprising which commenced in 1936 and was finally put down by the British in $1939 .{ }^{26}$ By then war was looming in Europe and British Prime Minister Neville Chamberlain took the view that it was more important to have the Arabs on-side than the Jews. ${ }^{27}$ In order to placate the Arabs, Britain placed restrictions on Jewish immigration and promised that Palestine would be given independence within ten years. ${ }^{28}$

Immediately after World War II, Palestine had an Arab population of approximately 1.06 million people and a Jewish population of approximately 554,000 people. ${ }^{29}$ In other words, the Arabs outnumbered the Jews two to one. 
The Zionist movement, through an organization known as the Jewish Agency, demanded that Britain allow the 100,000 Jews displaced by World War II to migrate to Palestine. ${ }^{30}$ Britain, which was preparing to give independence to Palestine, decided to continue with the quota of 1,500 Jewish migrants per month that it had imposed in 1939. ${ }^{31}$ The military arm of the Jewish Agency, Haganah, and two underground Zionist organizations responded by waging an undeclared war or campaign of terror (again, depending on your point of view) against British authorities in Palestine. ${ }^{32}$

By 1947, Britain had had enough and asked the United Nations to sort out the problem. The United Nations established an eleven-member Special Committee on Palestine (UNSCOP), which reported to the United Nations General Assembly in August 1947. The majority (seven members) ${ }^{33}$ recommended the partition of Palestine into a Jewish state comprising 56 per cent of the territory and an Arab state comprising 43 per cent of the territory. It also recommended the internationalization of Jerusalem, since the city was holy to Jews, Christians, and Muslims. ${ }^{34}$ A minority (three members) recommended that independent Palestine be established as a federal state. ${ }^{35}$ The eleventh member (Australia) chose to abstain from making any recommendation. ${ }^{36}$ The Zionists were pleased with the majority recommendations. The Arabs were not, since what was being recommended was that a minority of the population get the majority of the territory. Nevertheless, on 29 November 1947, the United Nations General Assembly passed a resolution which endorsed the partition recommendation by a two-thirds majority. ${ }^{37}$

According to the historian Tom Segev, "No one believed in the UN's map, everyone knew there would be war." 38 However, Britain was determined to wash its hands of Palestine. ${ }^{39}$ The British High Commissioner and the last British troops left Palestine on 14 May 1948, the very day that the mandate terminated. ${ }^{40}$ On that day, David BenGurion, the head of the Jewish Agency, declared that the state of Israel had come into being. Palestine's Arab neighbours responded by sending in their troops. By the end of 1948, the Israeli forces had routed them all. ${ }^{41}$ In the first part of 1949, Israel signed a series of armistice agreements with its neighbours, i.e. with Egypt, Jordan, Lebanon, and Syria. Under the agreements Israel got to keep considerably more territory than it would have received under the United Nations partition arrangement (77 per cent of mandatory Palestine). ${ }^{42}$ Jordan and Egypt respectively were left in control of those parts of mandatory Palestine known as the West Bank and the Gaza Strip (the remaining 23 per cent of mandatory Palestine). ${ }^{43}$
On 27 January 1949, Britain and Australia announced their recognition of Israel. ${ }^{44}$ Australia also moved the formal resolution recommending Israel's admission as a member of the United Nations. ${ }^{45}$ On 18 May 1949, Israel's application for United Nations membership was approved. At the beginning of 1950, the new state of Israel had a population of one million Jews and about 150,000 Arabs. This was because on the one hand Jewish immigration to Israel continued while on the other most Arabs inhabitants had fled or been expelled during the 1948 war. ${ }^{46}$ The extent to which displacement was caused by the latter rather than the former is the subject of bitter contestation, ${ }^{47}$ since even at the time mass expulsion was regarded as a war crime and a crime against humanity. ${ }^{48}$ In any event, the displaced Arabs are not regarded as Israeli nationals under Israeli law. ${ }^{49}$ Moreover, they are not permitted by Israel to return to the homes they left. Whether Israel's position on nationality and/or return is defensible under international law is, unsurprisingly, the subject of further controversy. ${ }^{50}$

After the 1948 war, 470,000 displaced Palestinians settled in camps in the West Bank and Gaza Strip. ${ }^{51}$ Over 280,000 more Palestinians also displaced during the 1948 war dispersed to neighbouring countries, with most going to Jordan, Lebanon, or Syria. ${ }^{52}$ During the Six Day War of 1967, in the course of which Israel fought with Egypt, Syria, and Jordan, further displacement occurred with 800,000 West Bank inhabitants and 150,000 Gaza Strip inhabitants fleeing into Jordan. ${ }^{53}$

After the 1967 war, those who remained in the West Bank and Gaza Strip found themselves living under Israeli rule though still without Israeli nationality. ${ }^{54}$ Pursuant to the 1994 Gaza-Jericho Agreement and the 1995 Interim Agreement, Israel transferred responsibility for civil governance of some parts of the occupied territories to the Palestinian Authority. ${ }^{55}$ However, the non-Jewish inhabitants of the occupied territories remain de jure stateless ${ }^{56}$ and, far from being protected by either Israel or the Palestinian Authority, are subjected to serious human rights abuses by both. These abuses include arbitrary deprivation of life; torture and other cruel, inhuman, or degrading treatment or punishment; arbitrary arrest and detention; arbitrary interference with privacy, family, and home; and denial of freedom of movement. ${ }^{57}$

All Palestinians living in Jordan, except those who fled from the Gaza Strip in 1967, have been permitted to acquire Jordanian citizenship and enjoy the rights which go with citizenship. ${ }^{58}$ However, most Palestinian refugees in Syria and Lebanon (including the descendants of the original refugees) are unable to acquire the citizenship of their host country. ${ }^{59}$ In Syria they at least enjoy many of the same rights as Syrian citizens do. ${ }^{60}$ However, in Lebanon they 
have extremely limited work rights, have no access to social assistance, are denied freedom of movement, and have, in fact, been persecuted at various times by state and non-state actors. ${ }^{61}$

\section{Palestinians and International Protection}

Asylum

Reference is often made to the fact that Article 14(1) of the United Nations Universal Declaration on Human Rights (UDHR) ${ }^{62}$ provides that "everyone has the right to seek and enjoy in other countries asylum from persecution." 63 However, the drafting history of the UDHR indicates that the provision cannot be read as meaning that an individual asylum seeker has the right to be granted asylum by the country of his choice or any country. ${ }^{64}$

At one stage in the drafting process, Article 14 did in fact provide that everyone had "the right to seek and be granted in other countries asylum from persecution." This formulation was strongly advocated by the World Jewish Congress, which had in mind the experience of German Jews who had attempted to flee the Holocaust but had been denied entry by other countries. However, Saudi Arabia proposed the deletion of the words "and be granted" and was supported in this by most Arab countries. Arab opposition to the inclusion of the words "and be granted" appears to have been a response to the mass displacement of Palestinians which was occurring at the time. According to Johannes Morsink, "[ $\mathrm{t}$ ] hese countries probably thought that a vote for the human right to be granted asylum would in effect saddle them with half a million refugees to cloth, feed, and house," though from their point of view the only just solution to the Palestinians' plight was repatriation.

The amendment proposed by Saudi Arabia was carried by a vote of eighteen to fourteen with eight abstentions. Australia and Britain were among the non-Arab countries to vote for the amendment. Britain proposed the present wording of Article 14 and was strongly supported by Australia, ${ }^{65}$ which, like Britain, did not wish to abandon "the right which every sovereign state possesses to determine the composition of its own population, and who shall be admitted to its territories." 66

\section{International Refugee and Stateless Persons Regimes}

Even though the international community in the immediate aftermath of World War II was not moved by the experience of that war to recognize a human right to be granted asylum, it was still faced with the pressing need to resolve the plight of the thousands displaced from home by the war. As part of the effort to do so, the United Nations General Assembly convened the Conference of Plenipotentiaries on the Status of Refugees and Stateless Persons in July 1951. The Confer- ence was charged with drafting a Convention Relating to the Status of Refugees and a Protocol thereto relating to the Status of Stateless Persons which took into account draft treaties already prepared by an ad hoc committee of the United Nations Economic and Social Council. ${ }^{67}$ The conference did indeed manage to draft and adopt a Refugee Convention but ended up leaving the proposed Protocol relating to the Status of Stateless Persons for another day. A second conference of plenipotentiaries was held in 1954 to deal with the Protocol. The conference ended up drafting and adopting not a Protocol to the Refugee Convention but rather a separate Statelessness Convention. This Statelessness Convention replicates mutatis mutandis most of the provisions of the Refugee Convention. The significant Refugee Convention provisions that the Statelessness Convention does not replicate are Article 31, which prohibits penalization of refugees for illegal entry or presence (providing certain conditions are met); Article 33, which prohibits refoulement of refugees ${ }^{68}$ and Article 35, which requires states to co-operate with the Office of the United Nations High Commissioner for Refugees in the exercise of its functions including supervision of the application of the provisions of the Refugee Convention. ${ }^{69}$

All refugees/stateless persons in a state party's territory have the right to have the provisions of the relevant Convention applied without "discrimination as to race, religion or country of origin,"70 the right of free access to the state party's courts, ${ }^{71}$ and the right to be issued with identity papers if they do not possess a valid travel document. ${ }^{72}$ All refugees/stateless persons in a state party's territory also have the right to receive the same treatment as the state's nationals with respect to religious freedom ${ }^{73}$ and elementary education" ${ }^{74}$ and treatment "not less favourable than that accorded to aliens generally in the same circumstances" with respect to property rights ${ }^{75}$ and education other than elementary education. ${ }^{76}$

Refugees/stateless persons "lawfully in" a state party's territory must not be expelled from its territory "save on grounds of national security or public order."77 In addition, all refugees/stateless persons "lawfully in" a state party's territory must be accorded the same rights of freedom of movement $^{78}$ and rights to engage in self-employment ${ }^{79}$ accorded to "aliens generally in the same circumstances."

All refugees/stateless persons "lawfully staying in" a state party's territory must be issued with travel documents for the purpose of travel outside its territory ${ }^{80}$ and accorded the same treatment as the state's nationals with respect to public relief and assistance ${ }^{81}$ and to labour and social security rights. ${ }^{82}$ All refugees/stateless persons "lawfully staying in" a state party's territory must also be accorded housing rights, ${ }^{83}$ rights of association, ${ }^{84}$ and rights to engage in 
wage-earning employment and practice "liberal professions" 85 that are "not less favourable than that accorded to aliens generally in the same circumstances."

Finally, each Convention provides that state parties "shall as far as possible facilitate the assimilation and naturalization" of the persons to whom the Convention applies. ${ }^{86}$ However, the exhortation falls short of imposing an obligation on a state party to grant its nationality to persons to whom the Convention applies. ${ }^{87}$ This fact is, of course, entirely in keeping with the refusal of states even to recognize a human right to be granted asylum.

Given that the Refugee Convention and Statelessness Convention confer certain rights on the persons to whom they apply, the next question which must be answered is whether either or both Conventions apply to stateless Palestinians. Refugee Convention Article 1A(2), as modified by Protocol Article I(2), ${ }^{88}$ provides that for the purposes of the Convention, the term "refugee" applies to any person who:

owing to a well-founded fear of being persecuted for reasons of race, religion, nationality, membership of a particular social group or political opinion, is outside the country of his nationality and is unable or, owing to such fear, is unwilling to avail himself of the protection of that country; or who, not having a nationality and being outside the country of his former habitual residence, is unable or, owing to such fear, is unwilling to return to it. ${ }^{89}$

However, Article 1D of the Refugee Convention provides:

This Convention shall not apply to persons who are at present receiving from organs or agencies of the United Nations other than the United Nations High Commissioner for Refugees protection or assistance.

When such protection or assistance has ceased for any reason, without the position of such persons being definitively settled in accordance with the relevant resolutions adopted by the General Assembly of the United Nations, these persons shall ipso facto be entitled to the benefits of this Convention.

Similarly, while Article 1(1) of the Statelessness Convention provides that for "the purpose of this Convention, the term "stateless person" means a person who is not considered as a national by any State under the operation of its law,' Article 1(2) provides:

This Convention shall not apply:

(i) To persons who are at present receiving from organs or agencies of the United Nations other than the United Nations
High Commissioner for Refugees protection or assistance so long as they are receiving such protection or assistance.

The persons intended to be excluded by these provisions from the international protection regimes created by each treaty were Palestinians. ${ }^{90}$ However, the drafting history of the Refugee Convention and the Statelessness Convention makes it clear that the reason for excluding them from the application of these treaties was that they were intended to be the beneficiaries of a separate and better international protection regime. ${ }^{91}$

On 11 December 1948 the UN General Assembly adopted Resolution 194, which confirmed the right of return of displaced Palestinians and also created the United Nations Conciliation Commission on Palestine (UNCCP), which was charged with facilitating their "repatriation, resettlement and economic and social rehabilitation."92 A year later, the UN General Assembly created the United Nations Relief and Works Agency for Palestine (UNRWA) as a temporary organization and charged it with providing emergency relief and social services to Palestinian refugees. ${ }^{93}$ UNRWA's limited mandate reflected the fact that UNCCP was supposed to quickly resolve the plight of displaced Palestinians. This didn't happen. By 1952, the UN General Assembly had stripped away most of UNCCP's original protection functions and it now exists in name only. ${ }^{94}$ UNRWA on the other hand has had many renewals of its mandate and continues to operate. ${ }^{95}$ Since 1993, UNRWA has defined a "Palestinian refugee" as any person who took refuge in its areas of operation

whose normal place of residence was Palestine during the period 1 June 1946 to 15 May 1948 and who lost both home and means of livelihood as a result of the 1948 conflict. $^{96}$

The children of men registered with UNRWA as "Palestinian refugees" can also register as Palestinian refugees. ${ }^{97} \mathrm{UN}$ RWA assists such individuals if they reside within its areas of operation in the Middle East.

Today, the reference to "organs and agencies of the United Nations other than the United Nations High Commissioner for Refugees " in Article 1D of the Refugee Convention and Article 1(2)(i) of the Statelessness Convention is usually read as a reference to UNRWA since UNCCP doesn't actually do anything anymore. Those who are in receipt of UNRWA's assistance are regarded as being locked out of the protection regimes of the Refugee Convention and Statelessness Convention, even though UNRWA's mandate does not extend to protection. In other words, UNRWA's mandate does not extend to promoting enjoyment of the kinds of rights set out in the Refugee Conven- 
tion and Statelessness Convention or to the most important aspect of the legal concept of protection, which is facilitation of a durable solution to the plight of the individual (in the form of repatriation or resettlement). ${ }^{98}$

Goodwin-Gill and Akram make very strong and persuasive arguments in support of the proposition that the second paragraph of Article 1D has the effect that "Palestinian refugees" who leave UNRWA's areas of operation immediately and automatically become entitled to the benefits of the Refugee Convention. ${ }^{99}$ Most state parties to the Refugee Convention accept that "Palestinian refugees" who make their way to places outside UNRWA's areas of operation are not excluded from Refugee Convention protection by Article 1D. However, most take the position that such individuals will only be entitled to Refugee Convention protection if they meet the Article 1A(2) definition of "refugee."100 Unfortunately, the determination usually made in relation to such individuals is that they do not meet the Article 1A(2) definition of "refugee."101

On 8 November 2002, the Full Court of the Federal Court of Australia decided the case of Minister for Immigration and Multicultural Affairs $v$. WABQ. ${ }^{102}$ The respondent in the case was a stateless Palestinian registered with UNWRA whose place of habitual residence was Syria. The Refugee Review Tribunal had found that upon leaving UNRWA's areas of operation the respondent ceased to be excluded from the benefits of the Refugee Convention by Article 1D. It had further found that the respondent had a well-founded fear of persecution if returned to Syria and was therefore a refugee within the meaning of the Refugee Convention. The latter finding was not challenged. However, the Minister for Immigration argued that it did not matter that the respondent met the Article 1A(2) definition of refugee, because Article 1D correctly interpreted excluded him from the application of the Convention. According to the Minister the correct interpretation of Article $1 \mathrm{D}$ was that a person entitled to receive assistance from UNRWA was excluded from the benefits of the Refugee Convention even if that person was no longer within UNRWA's areas of operation for whatever reason (in this case because he had been forced to flee).

The Full Court allowed the Minister's appeal because it found that the Refugee Review Tribunal had indeed erred in its interpretation of Article 1D. However, the Full Court did not accept the Minister's interpretation of Article 1D either.

Tamberlin J. (with whom Moore J. agreed in a separate judgment) held that the first paragraph of Article 1D had the effect that Palestinians as a group were excluded from the benefits of the Convention because as at 28 July 1951 they were protected by UNCPP and assisted by UNRWA.
However, the second paragraph of Article $1 \mathrm{D}$ required a factual inquiry into whether UNCPP still performed its protection mandate. If it did not, Palestinians were entitled to the benefits of the Refugee Convention as long as they met the definition of refugee set out in Article 1A(2). ${ }^{103}$ In the case before the court, of course, the respondent had already been found to fall within the definition and that finding had not been challenged. The case was, therefore, remitted back to the member of the Refugee Review Tribunal who had made the original decision so that a finding of fact could be made on whether UNCPP was still performing its protection mandate but without the need for the respondent to re-establish his refugee status if the finding about UNCPP was (as the court strongly indicated it ought to be) that it was no longer performing its protection mandate. Since the decision in Minister for Immigration and Multicultural Affairs v. WABQ, the Refugee Review Tribunal has been applying the Refugee Convention to Palestinians on the basis that UNCPP has not provided Palestinians with protection since 1951 or thereabouts. ${ }^{104}$

If states interpret Article 1(2)(i) of the Statelessness Convention consistently with their interpretation of Article 1D of the Refugee Convention, as they logically ought to do, then most states ought to take the position that once de jure stateless Palestinians are outside UNRWA areas of operation they are no longer excluded from the benefits of the Statelessness Convention by Article 1(2)(i). ${ }^{105}$ If Australia interprets Article 1(2)(i) of the Statelessness Convention consistently with the Full Federal Court's present interpretation of Article 1D of the Refugee Convention, then it ought to take the position that Article 1(2)(i) no longer excludes Palestinians from claiming the benefits of the Statelessness Convention. However, since Australia's implementation of its Statelessness Convention obligations is not the subject of any kind of judicial oversight, ${ }^{106}$ it cannot be taken for granted that the executive government will feel constrained to apply the reasoning in $W A B Q$ by analogy to its interpretation of Article 1(2)(i).

Assuming that Palestinians as a group are not (or a particular Palestinian is not) excluded from the application of the Statelessness Convention by Article 1(2)(i), they may still be caught by another of the exclusions listed in Article 1(2). In the present context, the most important of these other exclusions is Article 1(2)(ii), which provides that the Statelessness Convention shall not apply

$[\mathrm{T}]$ o persons who are recognized by the competent authorities of the country in which they have taken residence as having the rights and obligations which are attached to the possession of the nationality of that country. 
Article 1E of the Refugee Convention contains an analogous exclusion from the application of that Convention. The only country in the world which could plausibly be argued to provide its stateless Palestinians residents with the sort of protection contemplated by Article 1(2)(ii) of the Statelessness Convention and Article 1E of the Refugee Convention (without actually conferring nationality) is Syria. ${ }^{107}$ However, Australia's Refugee Review Tribunal seems to accept that the rights which Palestinians enjoy in Syria are not sufficient to trigger the Article 1E exclusion. ${ }^{108}$

\section{International Human Rights Regime}

In The Status of Palestinian Refugees in International Law, Takkenberg notes that not only is it the case that relatively few states are parties to the Statelessness Convention but even in those states few stateless persons have succeeded in actually claiming the benefits of that Convention. ${ }^{109} \mathrm{He}$ suggests that one reason for this is that the ability of an individual to enjoy most of the rights set out in that Convention is dependent not only on being stateless but also on having some kind of lawful immigration status in the country concerned. ${ }^{110}$ The immigration status of an individual while in a country of which he or she is not a national is entirely governed by the domestic law of that country. International law has nothing to say about the matter. However, international law does have something to say about another matter and that is what rights are due to human beings as such regardless of other status.

Australia is one of the 153 states $^{111}$ that are party to the International Covenant on Civil and Political Rights (ICCPR $)^{112}$ and one of the 150 states $^{113}$ that are party to the International Covenant on Economic, Social and Cultural Rights (ICESCR). ${ }^{114}$ Most of the human rights obligations set out in these two treaties are also customary international law obligations binding as such even on states which are not parties to the treaties. ${ }^{115}$ Some of these customary international law human rights obligations have, in fact, become peremptory norms of international law, which as such override all inconsistent rules of international law whether sourced in treaty or custom. ${ }^{116}$ More significantly, however, there is growing acceptance of the proposition that international human rights law as a body of law has primacy over all other international law, including the specialized international legal regimes put in place by states to govern particular fields of activity. ${ }^{117}$ Of course, it is only necessary to determine which of two potentially applicable legal rules has primacy over the other in a given situation, if the rules are actually in conflict. Both the Statelessness Convention and the Refugee Convention make it clear that their provisions are intended to supplement rather than erode the protections provided to stateless persons and refugees re- spectively by other sources of law. Article 5 of the Statelessness Convention provides:

Nothing in this Convention shall be deemed to impair any rights and benefits granted by a Contracting State to stateless persons apart from this Convention.

Article 5 of the Refugee Convention contains an analogous provision. In short, it is possible to turn to international human rights law to fill the gaps in the international protection of stateless persons and refugees that have been left by the two treaties specifically intended to address the situation of such persons. ${ }^{118}$ Australia as a party to the ICCPR has undertaken to:

respect and to ensure to all individuals within its territory and subject to its jurisdiction the rights recognized in the present Covenant, without distinction of any kind, such as race, colour, sex, language, religion, political or other opinion, national or social origin, property, birth or other status. ${ }^{119}$

Among other things the ICCPR provides that "[e]very human being has the inherent right to life" and the right not to be arbitrarily deprived of it, ${ }^{120}$ that "[n]o one shall be subjected to torture or to cruel, inhuman or degrading treatment or punishment," 121 and that "[e]veryone has the right to liberty and security of person" and the right not to be arbitrarily arrested or detained. ${ }^{122}$ The only ICCPR rights which in their own terms are owed by a state party to a subcategory of individuals rather than to all individuals are the right to freedom of movement, ${ }^{123}$ the right to due process before expulsion, ${ }^{124}$ and the right to participate in public affairs, vote, and hold political or public office. ${ }^{125}$ Moreover, the United Nations Human Rights Committee ${ }^{126}$ has been at pains to emphasize that:

In general, the rights set forth in the Covenant apply to everyone, irrespective of reciprocity, and irrespective of his or her nationality or statelessness.

Thus, the general rule is that each one of the rights of the Covenant must be guaranteed without discrimination between citizens and aliens. ${ }^{127}$

Australia as a party to ICESCR has pursuant to Article 2(1) undertaken:

to take steps, individually and through international assistance and co-operation, especially economic and technical, to the maximum of its available resources, with a view to achieving progressively the full realization of the rights recognized in the 
present Covenant by all appropriate means, including particularly the adoption of legislative measures.

The rights recognized in ICESCR include "the right of everyone to the opportunity to gain his living by work which he freely chooses or accepts"; 128 "the right of everyone to social security, including social insurance"; ${ }^{129}$ and "the right of everyone to an adequate standard of living for himself and his family, including adequate food, clothing and housing." 130

The obligation imposed upon states by Article 2(1) is greater than may at first be apparent. As interpreted by the United Nations Committee on Economic, Social and Cultural Rights, ${ }^{131}$ Article 2(1) imposes a "minimum core obligation" on States to realise immediately "minimum essential levels of each of the rights" contained in the ICESCR. ${ }^{132}$ Beyond satisfaction of the minimum core obligation, even developed countries may be able to plead lack of resources as a reason for failing, at a given point in time, to realize fully the rights contained in the ICESCR. ${ }^{133}$ However, it is important to note that ICESCR Article 2 continues as follows:

(2) The State Parties to the present Covenant undertake to guarantee that the rights enunciated in the present Covenant will be exercised without discrimination of any kind as to race, colour, sex, language, religion, political or other opinion, national or social origin, birth or other status. ${ }^{134}$

This means that state parties, in according the rights set out in ICESCR to whatever extent, must accord them to all persons within its jurisdiction without discrimination on the basis, inter alia, of citizenship status. ${ }^{135}$ The only exception to this is contained in Article 2(3) of ICESCR, which provides:

(3) Developing countries, with due regard to human rights and their national economy, may determine to what extent they would guarantee the economic rights recognised in the present Covenant to non-nationals.

The exception applies only in respect to economic rights and can be relied upon only by developing countries ${ }^{136}$ (not developed countries such as Australia).

In his 2003 Final Report on the Rights of Non-Citizens the UN Special Rapporteur on the Rights of Non-Citizens summarized the conclusion of his review of international human rights law thus:

all persons should by virtue of their essential humanity enjoy all human rights unless exceptional distinctions, for example, be- tween citizens and non-citizens, serve a legitimate State objective and are proportional to the achievement of that objective. $^{137}$

This is another way of saying that differential treatment of citizens and non-citizens is only permissible if the difference in treatment does not breach the principle of non-discrimination, which is almost certainly a peremptory norm of international law. ${ }^{138}$ The legitimacy of aims and proportionality of means can of course be debated at length, especially in the context of determining the extent to which non-citizens should be accorded economic and social rights. Even in that context, however, there is a bottom-line proposition which emerges with clarity from the jurisprudence of the Committee on Economic, Social and Cultural Rights: there can be no justification for differential treatment which involves denying to non-nationals the minimum essential levels of ICESCR rights necessary for survival. ${ }^{139}$

\section{The Plight of Stateless Palestinians in Australia}

Australia divides non-citizens into two categories: lawful and unlawful. A non-citizen in Australia who "holds a visa that is in effect" is a lawful non-citizen. ${ }^{140}$ Visas can be permanent (giving permission to remain in Australia indefinitely) or temporary (giving permission to remain in Australia for a specified period or until the happening of a specified event). ${ }^{141}$ Visas may also be subject to specified conditions, for example, a condition preventing the holder from engaging in any work in Australia. ${ }^{142}$ A non-citizen who is not a lawful non-citizen is an unlawful non-citizen. ${ }^{143}$ Sections 189 and 196 of the Migration Act provide that an unlawful non-citizen in Australia's migration zone (other than an excised offshore place) must be detained until removed from Australia, deported, or granted a visa.

Non-citizens in Australia who invoke Australia's international protection obligations are permitted to make protection visa applications. The basic criterion for the grant of a protection visa is that the applicant is "a non-citizen in Australia to whom the Minister is satisfied Australia has protection obligations under the Refugee Convention as amended by the Refugee Protocol" or is the spouse or dependant of a protection visa holder. ${ }^{144}$ The Migration Act does not give the primary-stage decision maker or the merits review tribunal the power to grant a protection visa to an applicant not meeting the criteria for grant of a protection visa. However, the Minister for Immigration has been given personal powers to substitute for a decision of the merits review tribunal another "more favourable" decision, "if the Minister thinks that it is in the public interest to do so." 145 In exercise of these powers, the Minister is able to grant a protection visa applicant whatever visa the Min- 
ister thinks fit, even if the applicant does not satisfy the criteria specified in the regulations for the grant of a visa of that class. Ministerial guidelines relating to the exercise of the Minister's powers of intervention among other things identify cases of non-citizens to whom Australia has protection obligations under the Convention Against Torture and/or the ICCPR as cases in which it may be in the public interest to substitute a more favourable decision. ${ }^{146}$ However, Australia's obligations under the Statelessness Convention are not specifically mentioned.

Requesting exercise of the Minister's powers of intervention is the first and only opportunity asylum seekers have to put non-Refugee Convention protection claims to a decision maker who actually has the ability to respond meaningfully to those claims. It is a protection mechanism which clearly does not meet minimum procedural standards. First, the Minister for Immigration does not even have to consider the exercise of the powers; i.e. their exercise is non-compellable. Second, the Minister is clearly not an independent decision maker in the sense of being independent of immigration control and other government interests potentially opposed to those of the asylum seeker. Finally, the claimant does not have effective access to judicial or other independent review.

The Minister's powers of intervention were exercised in 590 cases in the period 1 July 2002 to 31 December 2003. It appears that most persons who successfully sought intervention were granted classes of visa other than protection visas. ${ }^{147}$ In recent times, the type of visa most likely to be granted has been a temporary spouse visa because the kind of case most likely to prompt intervention is that of "an in-community applicant with an Australian citizen child and Australian citizen/permanent resident partner."148 However, use has also been made of a wide range of other visa classes. ${ }^{149}$ By contrast, prior to 1999 it was almost always the case that a protection visa was granted following ministerial intervention. ${ }^{150}$ Johanna Stratton infers from this change (correctly, I suspect) that the Australian Government has made a policy decision to avoid granting protection visas following intervention, in order to reinforce its message that Australia is not a "soft touch" for asylum seekers. ${ }^{151}$ In short, it is far from satisfactory that Australia's fulfillment of its obligations under the Statelessness Convention is dependent on the uncertain discretion of the Minister for Immigration. The upshot is that those entitled to Australia's protection under the Statelessness Convention are unlikely to receive it, unless they happen to be "refugees" also.

Mr. Al Masri was a Palestinian from the Gaza Strip who arrived in Australia without authorization and thereby became an unlawful non-citizen. He made a protection visa application, which was rejected at both primary and merits review stages on the basis that Australia did not owe him protection obligations under the Refugee Convention. Section 198(1) of the Migration Act provides that an "officer must remove as soon as reasonably practicable an unlawful non-citizen who asks the Minister, in writing, to be so removed." 152 Immediately upon receiving the negative merits review decision, Mr. Al Masri made a written request to be returned to the Gaza Strip and did not at any stage thereafter seek to remain in Australia. Whether the Minister for Immigration might have been moved to exercise the ministerial powers of intervention on the basis of Australia's obligations under the Statelessness Convention must therefore remain a matter of speculation.

Israel did not oppose Mr. Al Masri's return to Gaza but would not permit Australia to return him via Israel. The alternatives acceptable to Israel were return through Jordan or Egypt, but those countries also refused to permit transit through their territories. Mr. Al Masri, who found himself faced with the prospect of indefinite detention in Australia, sought a court order for release.

The judge at first instance held that the relevant provisions of the Migration Act were

to be construed as authorising detention only for so long as: the minister is taking all reasonable steps to secure the removal from Australia of a removee as soon as is reasonably practicable; [and] the removal of the removee from Australia is "reasonably practicable", in the sense that there must be a real likelihood or prospect of removal in the reasonably foreseeable future. ${ }^{153}$

His Honour then found as a matter of fact that there was no real likelihood or prospect of $\mathrm{Mr}$. Al Masri's removal in the reasonably foreseeable future and accordingly ordered Mr. Al Masri's release from detention. The Minister for Immigration appealed the decision to the Full Federal Court of Australia.

Following the first-instance decision in the Al Masri case, two competing lines of authority developed in the Federal Court of Australia. One line of authority followed the Al Masri decision. The other line of cases did not, on the basis that the decision was plainly wrong. On 15 April 2003, the Full Federal Court handed down its decision in Minister for Immigration and Multicultural Affairs v. Al Masri. ${ }^{154}$ The Court emphasized that it was a principle of statutory construction that legislation ought not to be read as curtailing fundamental rights or freedoms unless there was a "clear expression of an unmistakable and an unambiguous intention" to do so. ${ }^{155}$ It then said, in the context of the case before it: 
The manifestation of such an intention must be such as to show clearly, and unmistakably, that the detention is to continue for as long as may be necessary and might even (as a theoretical possibility) be permanent, that it is intended that detention should continue without foreseeable end irrespective of the age, gender, personal or family circumstances of the person, irrespective of the unlikelihood (if such be the case) of a person absconding and irrespective of the absence (if such be the case) of any threat presented to the Australian community of a person detained. ${ }^{156}$

The Court held that the statutory scheme of mandatory detention manifested no such clear intention. Rather, it seemed to have been assumed by Parliament that detention would always come to an end one way or another. The Court, therefore, agreed with the first-instance judge that as a matter of statutory construction the power to detain was limited "to circumstances where there is a real likelihood or prospect of the removal of the person from Australia in the reasonably foreseeable future."157 It commented that it felt "fortified" in its conclusion by the fact that such a construction also accorded with the principle that so far as its language permits a statute should be read as conforming with Australia's treaty obligations, including under Article 9(1) of the ICCPR (the prohibition on arbitrary detention). ${ }^{158}$

Although the first instance Al Masri decision was upheld by the Full Federal Court in Minister for Immigration and Multicultural Affairs v. Al Masri, the Australian Government was far from pleased and it became evident that the High Court of Australia would have to settle the matter. Special leave to appeal the Full Federal Court decision in $A l$ Masri was refused by the High Court on the basis that the Government had subsequently managed to procure the return of Mr. Al Masri to Gaza. However, appeals to the Full Federal Court from two first-instance Federal Court decisions which raised the same question of law as was raised by the Al Masri case were removed to the High Court for resolution. On 6 August 2004, the High Court handed down its decisions in these two cases. In each case, the court was divided four to three, with the majority holding that the Al Masri decision was not good law. The judges' reasons for decision are set out in full in Al-Kateb v. Godwin. ${ }^{159}$

Mr. Al-Kateb was a stateless ${ }^{160}$ Palestinian who was born and spent most of his life in Kuwait. He arrived in Australia without authorization and thereby became an unlawful non-citizen subject to detention. He made a protection visa application which was rejected at both primary and merits review stages and an application for judicial review of the visa decision which was also unsuccessful. ${ }^{161}$ At this point, Mr. Al-Kateb made a written request to be removed from Australia, nominating Kuwait or Gaza as preferred destina- tions. ${ }^{162}$ As in the case of Mr. Al Masri, however, the Australian Department of Immigration was unable to find any country prepared to allow entry to Mr. Al-Kateb. The firstinstance judge found on the evidence there was no real likelihood or prospect of removal in the reasonably foreseeable future, ${ }^{163}$ but, choosing to follow the line of authority holding that Al Masri v. Minister for Immigration and Multicultural Affairs and Indigenous Affair was wrongly decided, ${ }^{164}$ held that Mr. Al-Kateb was not entitled to release from detention. ${ }^{165}$

The High Court majority (McHugh, Hayne, Callinan, and Heydon JJ. ${ }^{166}$ held that the relevant provisions of the Migration Act, by providing that detention of an unlawful non-citizen must continue "until" the occurrence of one of three specified events (i.e. grant of a visa, removal, or criminal deportation), had the effect of unambiguously authorizing the indefinite detention of unlawful non-citizens in the unfortunate position of neither qualifying for the grant of a visa nor, in practice, being removable/deportable from Australia in the foreseeable future. In particular, section 198 by imposing a duty to effect removal "as soon as reasonably practicable" did not thereby impose any kind of temporal limitation on detention.

According to Hayne J. (McHugh and Heydon JJ. agreeing),

The duty remains unperformed: it has not yet been practicable to effect removal. That is not to say that it will never happen.

This appellant's case stands as an example of why it cannot be said that removal will never happen. His prospects of being removed to what is now the territory in Gaza under the administration of the Palestinian Authority are, and will continue to be, much affected by political events in several countries in the Middle East. It is not possible to predict how those events will develop ....

Because there can be no certainty about whether or when the non?citizen will be removed, it cannot be said that the Act proceeds from a premise (that removal will be possible) which can be demonstrated to be false in any particular case.... And even if, as in this case, it is found that "there is no real likelihood or prospect of [the non-citizen's] removal in the reasonably foreseeable future", that does not mean that continued detention is not for the purpose of subsequent removal. The legislature having authorised detention until the first point at which removal is reasonably practicable, it is not possible to construe the words used as being subject to some narrower limitation such, for example, as what Dixon J referred to in Koon Wing Lau as "a reasonable time". ${ }^{167}$

Having decided the question of statutory construction, the majority judges had to consider whether the statutory 
provisions were, as argued by the appellant, constitutionally invalid. All four majority judges held that the provisions were constitutionally valid, being an exercise of the power conferred on the Australian Parliament by section 51(xix) of the Australian Constitution to legislate with respect to aliens which in their view did not infringe the separation of powers provided for by Chapter III of the Constitution.

Asylum-seeker advocates were horrified by the High Court decision, pointing out that as a result of it some stateless non-citizens faced the prospect of being held in Australian immigration detention for literally the rest of their lives. The Minister for Immigration denied this was the case, pointing out in her turn that she had the powers of intervention discussed earlier in this article which she was willing to exercise in appropriate cases. ${ }^{168}$ In order to demonstrate her bona fides she ordered a review of all cases affected by the High Court decision. ${ }^{169}$ Twenty-four cases were reviewed. ${ }^{170}$ The Minister granted bridging visas to the individuals concerned in nine cases where the person had been "cooperative with removal arrangements," their identity had been "firmly established," and removal was "likely to be protracted." ${ }^{171}$ In thirteen other cases the Minister refused to grant a visa, which in three cases meant the re-detention of persons previously released by court order. ${ }^{172}$ The remaining two cases were still under review at the time of writing.

In order to escape characterization as "arbitrary" under international law, detention must be permitted by domestic law and must also be a necessary and proportionate means of achieving a legitimate end. ${ }^{173}$ Detention would be proportionate, if the importance to society of the end to be achieved by detention could reasonably be said to outweigh the importance to the individual of physical liberty and the negative impact on the individual of deprivation of liberty. Since the negative impact of detention on the individual tends to increase as the duration of detention increases, ${ }^{174}$ duration of detention is a relevant factor in assessing proportionality. It defies credulity to suggest that indefinite detention of persons who cannot be removed from Australia could possibly be a proportionate means of achieving the objective of immigration control. Thus the thirteen individuals, including stateless Palestinians, to whom the Minister refused to grant visas, are being subjected to arbitrary detention in contravention of Article 9(1) of the ICCPR. ${ }^{175}$

The purpose of a bridging visa, as the name implies, is to bridge the time that elapses while a substantive visa application is being processed or while arrangements are being made for a non-citizen to depart Australia. In general, however, unauthorized arrivals are not eligible for the grant of a bridging visa, which is why grant of such a visa in the nine cases above mentioned required exercise of the Minister's powers of intervention. A non-citizen with a bridging visa has the status of a lawful non-citizen and is, therefore, not subject to immigration detention. The problem with court-ordered release from detention was that all that it procured for stateless persons was the dubious benefit of being at liberty in the community but without lawful immigration status or clear rights. I am informed by practitioners familiar with the cases that, lawful status apart, the situation of the nine individuals released on bridging visas is as unenviable. In particular, the bridging visas have been granted subject to the conditions that the holders must not engage in work, studies, or training in Australia.

An Australian citizen or permanent resident (i.e. permanent visa holder) who has inadequate means of support will usually fall within one of the categories of persons entitled to a social security payment under the Social Security Act 1991 (Cth). If all else fails, an Australian citizen or permanent resident with inadequate means of support is able to seek exercise of the discretion of the Secretary of the Commonwealth Department of Family and Community Services to make a payment known as a "special benefit" payment. ${ }^{176}$ However, with the exception of certain protection visa applicants who are able to meet very restrictive eligibility criteria, ${ }^{177}$ bridging and other temporary visa holders are not able to access Commonwealth funded social assistance. Australia also has a taxpayer-funded "universal" health insurance scheme, Medicare, which ensures that Australian citizens, Australian permanent residents, New Zealand citizens, and, subject to certain eligibility criteria, permanent visa applicants are able to access medical services without payment. ${ }^{178}$ Stateless Palestinians, who have already been through the protection visa application process and have been unsuccessful, are unable to access any of this Commonwealth-funded social assistance. In most cases, they are not able to access State/Territory or local government funded social assistance either. ${ }^{179}$ They must turn, therefore, to community sector welfare agencies to have their survival needs met. That these needs will be met is far from certain.

The Statelessness Convention only requires that work rights and social assistance rights be given to stateless persons "lawfully staying in" the state party's territory. ${ }^{180}$ Goodwin-Gill takes the view that the same phrase used in the Refugee Convention means "something more than mere lawful presence." 181 While stateless persons on bridging visas are lawfully present in Australia, it could well be argued that they are not "lawfully staying in" Australia in the sense of being given resident status. While it appears to me that allowing states to so interpret "lawfully staying in" runs the risk of rendering most of the provisions in the 
Statelessness Convention (and Refugee Convention) meaningless, I need not pursue the question here since it is possible to turn instead to ICESCR. As noted in the previous section, the Committee on Economic, Social and Cultural Rights has yet to be convinced that any policy objective is so important that refusing to meet the basic survival needs of particular individuals (as Australia is in relation to some stateless Palestinians) can be considered a proportionate method of achieving that objective. Australia's treatment of stateless Palestinians in the community (who are not protection visa applicants) is, therefore, in breach of its obligations under ICESCR.

\section{Taking Responsibility for the Past}

Each human person is able to imagine possible futures and to will and act to achieve one future rather than another. ${ }^{182}$ It is an attribute that makes human beings unique among living creatures. For practical purposes, national societies too can be ascribed agency in the sense that the individuals who make it up collectively will and act to achieve a chosen future. Most of us do conceive of ourselves as participating in a collective national project. Moreover, even those of us who are alienated from the goals of this collective project are still participating in it, if only by accepting the benefits generated through it. Confronted with the reality that there are other human beings in the world, the moral question that arises is how we as individuals and national societies should take account of this in our own willing and acting. The reason this article has dwelt so much on history is that every decision we make as individuals and societies we make in the context of a past that cannot be changed. Being morally responsible requires of us an "ex post facto account for what has been done" as well as a taking into account of the welfare of others in the "forward determination of what is to be done." ${ }^{183}$ Our past actions may already have given particular persons moral claims upon us that must be taken into account in the decision we are faced with now. ${ }^{184}$

One category of persons to whom it would be widely accepted I have special duties arising out of past actions consists of those to whom I have made promises understood to be binding. ${ }^{185}$ My duty is to keep my promise. Likewise, if our state makes such promises on our behalf it ought to keep those promises. ${ }^{186}$ By becoming party to the Refugee Convention, Statelessness Convention, ICCPR, and ICESCR, Australia has made promises, which since made ought not to be broken. ${ }^{187}$ It has been demonstrated in this article that if Australia took its duty of promise keeping as seriously as it ought, the circumstances of stateless Palestinians in Australia would be vastly improved without the need to invoke any other moral duties.
Another category of persons to whom it would be widely accepted that I have special duties arising out of past action consists of persons that I have wrongfully harmed. ${ }^{188} \mathrm{My}$ duty is to make reparation. Analogously, if the state institutions through which we act collectively wrongfully harm others we have collective duties to repair the harm. However, many of us refuse to accept that this is so where the wrongs in question were committed before we were born. Ross Poole puts the question in these terms:

By what line of inheritance do contemporary Australians inherit the sins of the predecessors? And which contemporary Australians? Is it only those of us of Anglo-Celtic stock whose ancestors came to Australia in the nineteenth century? Should we exclude those recent immigrants, especially those whose background is free from the taints of European colonialism and imperialism? And what of those Australians whose ancestors had no choice in the decision to migrate, but were brought over as convicts? ${ }^{189}$

Poole's answer is that our responsibility for past actions results from our identification with the entity, which performed those actions. In his words,

A national identity involves, not just a sense of place, but a sense of history. The history constitutes the national memory, and it provides a way of locating those who share that identity within a historical community.... Acquiring a national identity is a way of acquiring that history and the rights and the responsibilities which go with it. The responsibility to come to terms with the Australian past is a morally inescapable component of what it is to be Australian. ${ }^{190}$

Elazar Barkan makes a similar argument ${ }^{191}$ and adds that if we are willing to be the beneficiaries of our forebears' endeavours, we must also take responsibility for redressing the wrongs inflicted on others in the course of those endeavours. ${ }^{192}$ Moreover, he demonstrates through detailed case studies that, in fact,

This desire to redress the past is a growing trend, which touches our life at multiple levels, and it is central to our moral self-understanding as individuals and members of groups the world over. $^{193}$

Australia was part of the British Empire until World War II. ${ }^{194}$ Even after it had ceased to be a formal part of the Empire it continued to make common cause with Britain and most Australians identified with British interests as their own. This was certainly the case in relation to Palestine throughout the time that Britain was the Mandatory power. ${ }^{195}$ The historical narrative at the beginning of this 
article was intended to demonstrate that the British Empire and later Australia as an independent nation have been deeply implicated in creating the present plight of stateless Palestinians. It is a plight created in part by our broken promises, ${ }^{196}$ our abuse of power, ${ }^{197}$ our willingness to welcome Israel as a legitimate member of the international community once it was established as a fact on the ground without first insisting on a just resolution of the plight of the Palestinians thereby rendered stateless, and our refusal to give legal expression to a meaningful right of asylum.

It is the case, of course, that the moral standards of particular societies change over time. Historical actions which Australians judge to be wrong by standards now prevailing were not necessarily perceived to be wrong at the time they were undertaken. In acknowledging this "presentist moral predicament," one of the examples Barkan gives is, in fact, the failure of Western nations, then steeped in a colonialist mentality, to recognize in the first part of the twentieth century that support for the creation of Israel redressed earlier injustice against the Jews at the price of inflicting new injustice upon the Arab Palestinians. ${ }^{198} \mathrm{He}$ suggests, "[w]hen we (re)classify historical acts as injustices, we presumably determine that were we to face similar choices, we would act differently." 199 In other words, the reclassification of past action is vital to our present moral self-understanding. ${ }^{200}$

It is worth emphasizing that the argument that Australia ought to take moral responsibility for the historical wrongs in which it was complicit does not let other people off the moral hook for their actions or vice versa. Quite clearly, Israel, the Arab states, and Palestinian leaders have over time played a large part in creating and maintaining the sorry circumstances in which stateless Palestinians find themselves. They, too, are morally responsible for those circumstances. As many philosophers have explained, the attribution of moral responsibility is not a zero-sum game. ${ }^{201}$ However, the question for Australians is what Australia should do to discharge its moral obligations. The treatment of stateless Palestinians in Australia and elsewhere from 1948 to the present day illustrates the continuing truth of Hannah Arendt's observation that:

The conception of human rights, based upon the assumed existence of a human being as such, broke down at the very moment when those who professed to believe in it were for the first time confronted with people who had indeed lost all other qualities and specific relationships - except that they were still human. ${ }^{202}$

Since the individual who is nothing but a human being cannot in fact enjoy all of their human rights anywhere, it is suggested that one means of redressing past wrongs to which Australia ought to give serious consideration is to heed the urging of Article 32 of the Statelessness Convention and "as far as possible facilitate the assimilation and naturalization" of stateless Palestinians in Australia who have nowhere else to turn.

\section{Postscript:}

Recent reforms to Australia's immigration detention regime have given the Minister for Immigration the power to ameliorate the plight of long-term detainees, including the stateless, if the Minister wishes. Since 16 June 2005, persons in immigration detention whose "removal from Australia is not reasonably practicable" for the time being have been eligible for the grant of a Removal Pending Bridging Visa (RPBV), provided the Minister is satisfied that the person "will do everything possible to facilitate" their removal from Australia and any visa applications (with specified exception) have been finally determined. They also have to meet character and national security requirements. Unfortunately, only detainees invited to do so by the Minister for Immigration are able to apply for a RPBV. As at 14 July 2005 the Minister had invited fifty-eight individuals to apply for a RPBV and forty-two of them had taken up the invitation. However, as at 13 February 2006 there had only been a total of thirty-one grants of RPBVs. If granted, a RPBV enables the holder to remain at liberty in the community until removal from Australia becomes reasonably practicable. Importantly, the holders of RPBVs are given some social assistance entitlements and have the right to work. Nevertheless, they remain in an unenviable state of limbo.

Since 29 June 2005 the Minister for Immigration has also had a personal and non-compellable power under section 195A of the Migration Act to grant a visa to a person who is in detention under section 189, if "the Minister thinks that it is in the public interest to do so." Exercising this power, the Minister is now able to bring any long-detention situation to an end by granting the detainee a bridging visa or indeed a substantive visa regardless of whether the person in question meets the usual visa criteria. During the period 1 July 2005 to 31 December 2005 the section 195A power was exercised eighteen times.

\section{Notes}

1. Ray Wilkinson, "Old Problems... New Realities" (2003) 3:132 Refugees Magazine 4 at 12-13.

2. This is the definition of statelessness set out in Article 1 of the Convention relating to the Status of Stateless Persons, 28 September 1954, [1974] A.T.S. 20 (entered into force generally 6 June 1960 and for Australia 13 March 1974) [Statelessness Convention]. It is also accepted as being the customary inter- 
national law definition of statelessness: Susan Akram and Terry Rempel, "Temporary Protection as an Instrument for Implementing the Right of Return for Palestinian Refugees" (2004) 22 Boston University International Law Journal 1 at 65. In addition to the de jure stateless, there are many more persons who are stateless in a practical sense (defacto stateless). These are people who are not, in fact, recognized as nationals by any country, because, for example, they cannot meet evidentiary requirements for establishing that they possess the nationality they claim. They, therefore, lack "effective nationality": B.S. Chimni, "Post-conflict Peace-building and the Return of Refugees: Concepts, Practices and Institutions" in Edward Newman and Joanne van Selm, eds., Refugees and Forced Displacement: International Security, Human Vulnerability and the State (Tokyo, New York, and Paris: United Nations University Press, 2003) 195 at 210.

3. See further below.

4. Carol Batchelor, "Stateless Persons: Some Gaps in Protection" (1995) 7:2, International Journal of Refugee Law 232 at 239.

5. Convention relating to the Status of Refugees, 28 July 1951, [1954] A.T.S. 5 (entered into force for Australia and generally on 22 April 1954) [Refugee Convention].

6. Supra note 2 .

7. As at 1 October 2004.

8. As at 1 October 2004.

9. Guy Goodwin-Gill and Susan Akram, "Amicus Brief on the Status of Palestinian Refugees under International Law" (2000/2001) 11 Palestine Yearbook of International Law 185 at 222.

10. Baruch Kimmerling, "The Formation of Palestinian Collective Identities: The Ottoman and Mandatory Periods” (2000) 36:2 Middle Eastern Studies 48 at 52.

11. Supra note 9 at 202.

12. Chaim Weizmann, President of the World Zionist Organisation, at the 1919 Paris Peace Conference, quoted in Kimmerling, supra note 10 at 61.

13. Supra note 10 at 54 .

14. Rashid Khalidi, Palestinian Identity: The Construction of Modern National Consciousness (New York: Columbia University Press, 1997) 96, citing estimates set out and justified in Justin McCarthy, The Population of Palestine: Population Statistics of the Late Ottoman Period and the Mandate (New York: Columbia University Press, 1990).

15. Cited in David Abernethy, The Dynamics of Global Dominance: European Overseas Empires, 1415-1980 (New Haven and London: Yale University Press, 2000) at 108.

16. Ibid. at $105,108$.

17. Ibid. at 105 .

18. David Harris, Cases and Materials on International Law, 5th ed. (London: Sweet and Maxwell, 1998) at 131.

19. In the International Status of South-West Africa Case the International Court of Justice reinforced the point that each of the League of Nations mandates was "created in the interests of the inhabitants of the territory, and of humanity in general, as an international institution with an international object - a sacred trust of civilisation...": International Status of SouthWest Africa Case (Advisory Opinion) [1950] ICJ Rep 128.

20. Abernethy, supra note 15 at 106.

21. Omar Dajani, "Stalled between Seasons: The International Legal Status of Palestine during the Interim Period" (1997) 26 Denver Journal of International Law and Policy 27 at 35. See also Rashid Khalidi, supra note 14 at 22-23, 213 fn. 5; supra note 9 at 206.

22. Council of the League of Nations, Palestine Mandate, 24 July 1922, online: cf2 http://www.mideastweb.org/mandate.htm.

23. Khalidi, supra note 14 at 21, 187-88.

24. Kimmerling, supra note 12 at 64-65.

25. Abernethy, supra note 16 at 116; William Keylor, A World of Nations: The International Order since 1945 (New York and Oxford: Oxford University Press, 2003) at 147.

26. Khalidi, supra note 14 at 189-90.

27. David Schafer, "The Seeds of Enmity" (2002) 62:5 The Humanist 9 at 12 .

28. Ibid.

29. See the report of the Anglo-American Committee of Inquiry 1946, online: cf2 http://www.mideastweb.org/angloamerican.htm, which states: "According to official estimates, the population of Palestine grew from 750,000 at the census of 1922 to $1,765,000$ at the end of 1944 . In this period the Jewish part of the population rose from 84,000 to 554,000 , and from 13 to 31 percent of the whole. Three-fourths of this expansion of the Jewish community was accounted for by immigration. Meanwhile the Arabs, though their proportion of the total population was falling, had increased by an even greater number - the Moslems alone from 589,000 to $1,061,000$. Of this Moslem growth by 472,000 , only 19,000 was accounted for by immigration. The expansion of the Arab community by natural increase has been in fact one of the most striking features of Palestine's social history under the Mandate." These particular historical figures do not appear to be now disputed by the Israelis or Palestinians. Almost the same figures appear in a document entitled Demography of Palestine and Israel, the West Bank \& Gaza, available on the Jewish Virtual Library Web site, online: <http://www.jewishvirtuallibrary.org/jsource/History/demograhics.html and in a document entitled Geography of Palestine on Palestine-Net, online: cf2 http://www.palestine-net.com/geography.

30. Keylor, supra note 25 at $147-48$.

31. Ibid. at 148 .

32. Ibid. at 148 .

33. Daniel Mandel, "A Good International Citizen: H V Evatt, Britain, the United Nations and Israel, 1948-49" (2003) 39:2 Middle Eastern Studies 82 at 82.

34. Keylor, supra note 25 at 148-49.

35. Ibid. at 149 .

36. Supra note 33 ..

37. Keylor, supra note 25 at 149. Australia's H.V. Evatt played a key role in securing the adoption of this resolution: Mandel, supra note 33 at 83. 
38. Quoted in Jonathan Greenberg, "Divided Lands, Phantom Limbs: Partition in the Indian Subcontinent, Palestine, China, and Korea" (2004) 57:2 Journal of International Affairs 7 at 9.

39. Greenberg, ibid.

40. Ibid. at 10; Lex Takkenberg, The Status of Palestinian Refugees in International Law (Oxford: Clarendon Press, 1998) 12.

41. Keylor, supra note 25 at 150.

42. Ibid.; Wadie Said, "Palestinian Refugees: Host Countries, Legal Status and the Right of Return" (2003) 21:2 Refuge 89 at 89.

43. Said, ibid. at 89; Kimmerling, supra note 10 at 69.

44. Mandel, supra note 33 at 98.

45. Ibid. at 99 .

46. Keylor, supra note 25 at 150.

47. Greenberg, supra note 39 at 10.

48. John Quigley, "Displaced Palestinians and a Right of Return" (1998) 39 Harvard International Law Journal 171 at 183, 220-21.

49. Takkenberg, supra note 40 at $183-84$.

50. See for example the opposing positions taken in Hussein Ibish and Ali Abunimah, "Point/Counterpoint: The Palestinians' Right of Return” (2001) 8 Human Rights Brief 4 and John Quigley, supra note 48, on the one hand and Marc Zell and Sonia Shnyder, "Palestinian Right of Return or Strategic Weapon?: A Historical, Legal and Moral Political Analysis" (2003) 8 Nexus, A Journal of Opinion 77 and Tanya Kramer, 'The Controversy of a Palestinian "Right of Return" to Israel' (2001) 18 Arizona Journal of International and Comparative Law 979 on the other.

51. Keylor, supra note 25 at 150.

52. Ibid.; Said, supra note 42 at 89.

53. Said, ibid. at 90.

54. Kimmerling, supra note 10 at 69.

55. United States Department of State, Country Reports on Human Rights Practices 2003 (2004), online: cf2 http://www.state.gov/ $\mathrm{g} / \mathrm{drl} / \mathrm{rls} / \mathrm{hrrpt} / 2003 / 27929 . \mathrm{htm} \#$ occterr.

56. Takkenberg, supra note 40 at 178-82.

57. Supra note 55.

58. Said, supra note 42 at 90 ; Akram and Rempel, supra note 2 at 117.

59. Supra note 9 at 224; Stefan Christoff, "The War against Palestinian Refugees in Lebanon" (2004) 38:2 Canadian Dimension 16 at 17; Keylor, supra note 25 at 150.

60. Said, supra note 42 at 90-91.

61. Ibid. at 91; Christoff, supra note 59; supra note 9 at 226-27.

62. The UDHR is not legally binding in and of itself, but many provisions of it have over time become customary international law. Existing state practice and opinio juris supports a contention that the right to seek asylum is now a customary international law right: Morten Kjaerum, "Refugee Protection between State Interests and Human Rights: Where Is Europe Heading?” (2002) 24 Human Rights Quarterly 513 at 515.

63. Unless otherwise stated, the discussion in this section is based on Johannes Morsink, "World War Two and the Universal Declaration” (1993) 15:2 Human Rights Quarterly 357.
64. S. Prakash Sinha, Asylum and International Law (The Hague: Martinus Nijhoff, 1971) at 93, endnote 10.

65. Frank Brennan, Tampering with Asylum: A Universal Humanitarian Problem (St. Lucia: University of Queensland Press, 2003) at $1-2$.

66. Tasman Heyes, Secretary of the Department of Immigration quoted in Brennan, ibid. at 2.

67. Nehemiah Robinson, "Convention Relating to the Status of Stateless Persons. Its History and Interpretation: A Commentary" (Institute of Jewish Affairs, World Jewish Congress, 1955).

68. The prohibition on refoulement is the key provision of the Refugee Convention Article 33(1) providing that no state party Shall expel or return ("refouler") a refugee, in any manner whatsoever to the frontiers of territories where his life or freedom would be threatened on account of his race, religion, nationality, membership of a particular social group or political opinion.”

However, according to Article 33(2), the Article 33(1) obligation does not apply in respect of a refugee whom: "there are reasonable grounds for regarding as a danger to the security of the country in which he is, or who, having been convicted by a final judgment of a particularly serious crime, constitutes a danger to the community of that country."

It was unnecessary to include a prohibition on refoulement in the Statelessness Convention since stateless persons do not necessarily face persecution in their country of habitual residence and those who do would fall within the terms of the Refugee Convention and be protected by that Convention.

69. It should be noted, however, that in 1996 the UN General Assembly broadened UNHCR's mandate to include activities promoting the international protection of stateless persons.

70. Refugee Convention, Article 3; Statelessness Convention, Article 3.

71. Refugee Convention, Article 16; Statelessness Convention, Article 16.

72. Refugee Convention, Article 27; Statelessness Convention, Article 27.

73. Refugee Convention, Article 4; Statelessness Convention, Article 4.

74. Refugee Convention, Article 22; Statelessness Convention, Article 22.

75. Refugee Convention, Article 13; Statelessness Convention, Article 13.

76. Refugee Convention, Article 22; Statelessness Convention, Article 22.

77. Refugee Convention, Article 32; Statelessness Convention, Article 31.

78. Refugee Convention, Article 26; Statelessness Convention, Article 26.

79. Refugee Convention, Article 18; Statelessness Convention, Article 18.

80. Refugee Convention, Article 28; Statelessness Convention, Article 28 . 
81. Refugee Convention, Article 23; Statelessness Convention, Article 23.

82. Refugee Convention, Article 24; Statelessness Convention, Article 24.

83. Refugee Convention, Article 21; Statelessness Convention, Article 21.

84. Refugee Convention, Article 15; Statelessness Convention, Article 15.

85. Refugee Convention Articles 17, 19; Statelessness Convention Articles 17, 19

86. Refugee Convention Article 34; Statelessness Convention Article 32.

87. Andrew Brouwer, "Statelessness in Canadian Context: A Discussion Paper" (UNHCR, July 2003) at 9.

88. Protocol relating to the Status of Refugees, 31 January 1967, [1973] A.T.S. 37 (entered into force generally on 4 October 1967 and for Australia on 13 December 1973).

89. Refugee Convention Article $1 \mathrm{~A}(1)$ defines an additional category of refugee, but it is a category which is of little relevance in the present day.

90. Supra note 9 at 232-36; Zell and Shnyder, supra note 50 at 110.

91. Susan Akram, "Palestinian Refugees and Their Legal Status: Rights, Politics, and Implications for a Just Solution" (2002) 31:3 Journal of Palestine Studies 36 at 40.

92. Quoted in Takkenberg, supra note 40 at 12; see also Akram, supra note 91 at 38 .

93. Takkenberg, supra note 40 at 28-29.

94. Ibid. at 28; Akram, supra note 91 at 42.

95. Takkenberg, supra note 40 at 31.

96. Consolidated Registration Instructions, 1 January 1993, para. 2.13, quoted in Takkenberg, supra note 40 at 77.

97. Takkenberg, supra note 40 at 80 .

98. Supra note 9 at 193-94; Akram and Rempel, supra note 2 at 57, fn. 251.

99. Supra note 9 at $230-50$.

100. Supra note 91 at $43-44$.

101. Ibid. at $44-45$.

102. [2002] FCAFC 329 (8 November 2002).

103. Minister for Immigration and Multicultural Affairs v. WABQ [2002] FCAFC 329 (8 November 2002) paras. 169-71.

104. See for example RRT Reference N04/48145 (19 July 2004); RRT Reference N03/47958 (7 April 2004); RRT Reference V03/15685 (12 March 2004).

105. This is the position in fact taken in German jurisprudence, for example: Takkenberg, supra note 40 at $189-90$

106. See further below.

107. Supra note 9 at 258.

108. See, for example, RRT Reference N01/37373 (29 June 2001). It is more usual for members of the Refugee Review Tribunal to express no view on the matter since the cases in which the point arises are cases in which stateless Palestinians, whose country of habitual residence is Syria, are claiming that they face persecution if returned there. The Refugee Review Tri- bunal takes the view that Article $1 \mathrm{E}$ cannot possibly refer to the alleged country of persecution.

109. Takkenberg, supra note 40 at 187.

110. Ibid. at $187 \mathrm{fn}$. 76 . See summary of rights above.

111. As at 1 October 2004.

112. International Covenant on Civil and Political Rights 19 December 1966, [1980] A.T.S. 23 (entered into force generally on 23 March 1976 and for Australia on 13 November 1980) [ICCPR].

113. As at 1 October 2004.

114. International Covenant on Economic, Social and Cultural Rights, 19 December 1966, [1976] A.T.S. 5 (entered into force generally on 3 January 1976 and for Australia on 10 March 1976) [ICESCR].

115. Francisco Forrest Martin, "Delineating a Hierarchical Outline of International Law Sources and Norms' (2002) 65 Saskatchewan Law Review 333 at 355-58.

116. Ibid. at 341-47. A peremptory norm of international law (jus cogens) is defined as "a norm accepted and recognized by the international community of states as a whole as a norm from which no derogation is permitted and which can be modified only by a subsequent norm of general international law having the same character": Vienna Convention on the Law of Treaties, 23 May 1969, [1974] A.T.S. 2 (entered into force for Australia and generally on 27 January 1980) at Article 53.

117. Dinah Shelton, "Hierarchy of Norms and Human Rights: Of Trumps and Winners" (2002) 65 Saskatchewan Law Review 299 at 304-7.

118. I am not alone in doing so. See, for example, Bobana Ugarkovic, "A Comparative Study of Social and Economic Rights of Asylum Seekers and Refugees in the United States and the United Kingdom” (2004) 32 Georgia Journal of International and Comparative Law 539; David Weissbrodt, Final Report on the Rights of Non-Citizens, UN Doc. E/CN.4/Sub.2/ 2003/23 (2003) para. 13, online: <http://wwwl.umn.edu/ humanrts/demo/noncitizenrts-2003.html>; and Ryszard Choleswinski, "Economic and Social Rights of Refugees and Asylum Seekers in Europe” (2000) 14 Georgetown Immigration Law Journal 709.

119. ICCPR, Article 2(1).

120. ICCPR, Article 6(1).

121. ICCPR, Article 7.

122. ICCPR, Article 9(1).

123. ICCPR Article 12(1) provides: "Everyone lawfully within the territory of a State shall, within that territory, have the right to liberty of movement and freedom to choose his residence."

124. ICCPR Article 13 provides: "An alien lawfully in the territory of a State Party to the present Covenant may be expelled therefrom only in pursuance of a decision reached in accordance with law and shall, except where compelling reasons of national security otherwise require, be allowed to submit the reasons against his expulsion and to have his case reviewed by, and be represented for the purpose before, the competent authority or a person or persons especially designated by the competent authority." 
125. ICCPR Article 25 provides: "Every citizen shall have the right and the opportunity, without any of the distinctions mentioned in article 2 and without unreasonable restrictions:

a) To take part in the conduct of public affairs, directly or through freely chosen representatives;

(b) To vote and to be elected at genuine periodic elections which shall be by universal and equal suffrage and shall be held by secret ballot, guaranteeing the free expression of the will of the electors;

(c) To have access, on general terms of equality, to public service in his country."

126. This is the body charged with supervising the implementation by state parties of their ICCPR obligations.

127. United Nations Human Rights Committee, General Comment 15: The Position of Aliens under the Covenant (1986) at paras. $1-2$.

128. Supra note 114, Article 6.

129. Ibid., Article 6.

130. Ibid., Article 11.

131. This is the body charged with supervising the implementation by state parties of their ICESCR obligations.

132. United Nations Committee on Economic, Social and Cultural Rights, General Comment No. 3: The Nature of States Parties' Obligations (1990) at para, 10.

133. Matthew Craven, The International Covenant on Economic, Social and Cultural Rights: A Perspective on Its Development (Oxford: Clarendon Press; New York: Oxford University Press, 1995) at 132-33.

134. When the words of Article 2(2) are contrasted with the words of Article 2(1) it becomes obvious that immediate realization of the obligation of non-discrimination is required: see ibid. at 181 .

135. Weissbrodt, supra note 118 at para. 7; Choleswinski, supra note 118 at 718-19.

136. Weissbrodt, supra note 118 at para. 19

137. Ibid., executive summary.

138. The first international decision to explicitly affirm this proposition was the Inter-American Court of Human Rights Advisory Opinion OC-18/03 on the Legal Status and Rights of Undocumented Migrants: see Beth Lyon, “The InterAmerican Court of Human Rights Defines Unauthorized Migrant Workers' Rights for the Hemisphere: A Comment on Advisory Opinion 18" (2004) 28 New York University Review of Law and Social Change 547 at 586-87.

139. Ryszard Choleswinski, "Enforced Destitution of Asylum Seekers in the United Kingdom: The Denial of Fundamental Human Rights" (1998) 10 International Journal of Refugee Law 462 at 493.

140. Migration Act 1958 (Cth), s. 13 [Migration Act].

141. Migration Act s. 30.

142. Migration Act s. 41.

143. Migration Act s. 14.

144. Migration Act s. 36(2).

145. Migration Act ss. 417 and 501J.
146. Department of Immigration and Multicultural and Indigenous Affairs [DIMIA], Migration Series Instruction 386: Guidelines on Ministerial Powers under sections 345, 351, 391, 417, 454 and 501J of the Migration Act 1958 (14 August 2003) para. 4.2.1. See further Savitri Taylor, “Australia's Implementation of Its Non-refoulement Obligations under the Convention Against Torture and Other Cruel Inhuman or Degrading Treatment or Punishment and the International Covenant on Civil and Political Rights" (1994) 17 University of New South Wales Law Journal 432.

147. For example, only twenty-four of the 866 protection visas granted in 2002-03 were granted following ministerial intervention: DIMIA, “Annual Report 2002-03” (2003), online: ttp://www.immi.gov.au/annual_report/annrep03/report28 .htm.

148. Johanna Stratton, Humanitarian Intervention in the Public Interest? A Critique of the Recent Exercise of $s 417$ Migration Act 1958 (Cth) (Honours thesis, Australian National University, 2002).

149. Ibid.

150. Ibid.

151. Ibid.

152. The rest of section 198 provides for the removal "as soon as reasonably practicable" of unlawful non-citizens who either have not made an application for a substantive visa or who have received final refusal of an application for a substantive visa even if the individual in question is opposed to such removal.

153. Al Masriv. Minister for Immigration and Multicultural Affairs and Indigenous Affairs (2002) 192 ALR 609, 619.

154. Minister for Immigration and Multicultural Affairs v. Al Masri [2003] FCAFC 70 (15 April 2003).

155. Ibid. para. 84 .

156. Ibid. para. 117.

157. Ibid. para. 137.

158. Ibid. para. 156.

159. Al-Kateb v. Godwin [2004] HCA 37 (6 August 2004). In the other case, Minister for Immigration and Multicultural and Indigenous Affairs v. Al Kafaji [2004] HCA 38 (6 August 2004), the judges for the most part simply refer to the reasons given in Al-Kateb.

160. It was not in dispute that Mr. Al-Kateb was a "stateless person" within the meaning of Article 1 of the Statelessness Convention: Al-Kateb v. Godwin [2004] HCA 37 (6 August 2004) para. 79 (per Gummow J.).

161. Al-Kateb v. Godwin [2004] HCA 37 (6 August 2004) para. 99 (per Gummow J.).

162. Ibid. para. 102.

163. SHDB v. Goodwin \& Ors [2003] FCA 300 (3 April 2003) para. 9.

164. His Honour was free to do this at the time as his decision was handed down a couple of weeks before the Full Federal Court's decision in Minister for Immigration and Multicultural Affairs v. Al Masri [2003] FCAFC 70 (15 April 2003). 
165. SHDB v. Goodwin \& Ors [2003] FCA 300 (3 April 2003) para. 10 referring to the reasons given by His Honour in the case of SHFB v. Goodwin \& Ors [2003] FCA 294 (3 April 2003). In fact, on 17 April 2003 pending the hearing of the High Court appeal, a consent order was made by another judge of the Federal Court releasing Mr. Al-Kateb from detention on certain conditions: Al-Kateb v. Godwin [2004] HCA 37 (6 August 2004) para. 107 (per Gummow J.).

166. The dissenting judges were Gleeson C.J., Gummow J., and Kirby J.

167. Al-Kateb v. Godwin [2004] HCA 37 (6 August 2004) paras. 229-31 (per Hayne J.).

168. Meaghan Shaw and Michael Gordon, 'Long-term Stateless to be Reviewed', The Age (Melbourne), 10 August 2004, cf2 http://www.theage.com.au/articles/2004/08/09/109202240 4082.html.

169. Ibid.

170. Amanda Vanstone, Al-Masri Decisions, VPS 126/2004 (31 August 2004), online: ttp://www.minister.immi.gov.au/media_releases/media04/v04126.htm at 1 September 2004.

171. Ibid.

172. Ibid.

173. A v. Australia, Communication No. 560/1993, 30 April 1997 (Human Rights Committee views) para. 9.4.

174. Allen Keller et al., "Mental Health of Detained Asylum Seekers. (Research Letters)” (2003) 362 (9397) The Lancet 1721.

175. Among those whom the Minister refused to release from detention was Mr. Peter Qasim who has been in immigration detention for over six years. Mr. Qasim claims to be a Muslim separatist from Kashmir. However, he is de facto stateless as the Indian government denies that he is an Indian national and has refused him entry. He has also been refused entry by eighty other countries. See Michelle Cazzulino, "A Man with No Past, No Future, No Hope," The Daily Telegraph (Sydney), 9 September 2004, 9.

176. Social Security Act s. 729.

177. See further, DIMIA, Fact Sheet 62: Assistance for Asylum Seekers in Australia (revised 20 November 2003), online: cf2 http://www.immi.gov.au/facts/62assistance.htm.

178. See further Health Insurance Commission, About Medicare, available online: ttp://www.hic.gov.au/yourhealth/our_services/am.htm at 11 November 2004 and DIMIA, supra note 177.

179. This assistance is usually tied to eligibility criteria that persons in their position would be unable to meet.

180. See above.

181. Guy Goodwin-Gill, The Refugee in International Law, $2^{\text {nd }}$ ed. (Oxford: Clarendon Press, 1996), 309.

182. Philip Allott, "Globalization from Above: Actualizing the Ideal through Law" in Ken Booth, Tim Dunne, and Michael Cox, eds., How Might We Live? Global Ethics in a New Century (Cambridge: Cambridge University Press, 2001) 61 at 61.

183. Hans Jonas, The Imperative of Responsibility: In Search of an Ethics for the Technological Age (Chicago: University of Chicago Press, 1984) at 92.
184. William David Ross, The Right and the Good (Oxford: Clarendon Press, 1930) at 21.

185. Ibid. at $21,27$.

186. Ibid. at $34-35$.

187. Recognition of this moral duty has led the Australian judiciary to the following propositions:

1. " $[\mathrm{T}]$ he fact that [a treaty] has not been incorporated into Australian law does not mean that its ratification holds no significance for Australian law. Where a statute or subordinate legislation is ambiguous, the courts should favour that construction which accords with Australia's obligations under a treaty or international convention to which Australia is a party, at least in those cases in which the legislation is enacted after, or in contemplation of, entry into, or ratification of, the relevant international instrument. That is because Parliament, prima facie, intends to give effect to Australia's obligations under international law": Minister for Immigration and Ethnic Affairs v. Teoh (1995) 128 ALR 353, 362 (per Mason C.J. and Deane J.).

2. " $[\mathrm{R}]$ atification by Australia of an international convention is not to be dismissed as a merely platitudinous or ineffectual act, particularly when the instrument evidences internationally accepted standards to be applied by courts and administrative authorities in dealing with basic human rights affecting the family and children. Rather, ratification of a convention is a positive statement by the executive government of this country to the world and to the Australian people that the executive government and its agencies will act in accordance with the Convention. That positive statement is an adequate foundation for a legitimate expectation, absent statutory or executive indications to the contrary, that administrative decision-makers will act in conformity with the Convention...." Minister for Immigration and Ethnic Affairs v. Teoh (1995) 128 ALR 353, 365 (per Mason C.J. and Deane J.).

188. Supra note 184 at 21, 27; Samuel Scheffler, Boundaries and Allegiances: Problems of Justice and Responsibility in Liberal Thought (Oxford: Oxford University Press, 2001) at 49-50.

189. Ross Poole, Nation and Identity (London and New York: Routledge, 1999) at 138.

190. Ibid. at 140-41.

191. Elazar Barkan, The Guilt of Nations: Restitution and Negotiating Historical Injustices (New York and London: W.W. Norton, 2000) at 344.

192. Ibid. at 320, 344.

193. Ibid. at xi.

194. The United Kingdom gave up control of its white dominions by the proclamation of an act of the UK Parliament called the Statute of Westminster in 1931. However, by its terms it supposedly did not apply to Australia until adopted by the Australian Parliament. Australian adoption took place in October 1942 pursuant to an act which was stated to have effect from 3 September 1939. The individual states of the Australian federation continued to hang on to at least the appearance of colonial dependency until passage by the UK 
and Australian parliaments of the Australia Act 1986. See W.J. Hudson and M.P. Sharp, Australian Independence: Colony to Reluctant Kingdom (Carlton: Melbourne University Press, 1988) at 130-37.

195. Suzanne Rutland, "Postwar Anti-Jewish Refugee Hysteria: A Case of Racial or Religious Bigotry?” (2003) 77 Journal of Australian Studies 69 at 73-74.

196. For example, Britain reneged on the promise made to the inhabitants of the Ottoman territories that it occupied during World War I that they would be allowed self-determination after the war.

197. Britain used its clout as a Principal Allied Power to obtain a League of Nations Mandate over Palestine designed to give effect to the Balfour Declaration rather than the principles contained in Article 22 of the League of Nations Covenant and did not even honour the terms of that mandate insofar as it required the development of self-governing institutions.

198. Supra note 191 at xxxiii.

199. Ibid. at xxxiii.

200. This is a moral stance which Australia has already taken in another context. In the watershed case of Mabo v. Queensland (No. 2) (1992) 107 ALR 1, which overturned the (until then) sacrosanct common law doctrine of terra nullius and recognized native title, Brennan J. explained:

"If the international law notion that inhabited lands may be classified as terra nullius no longer commands general support, the doctrines of the common law which depend on the notion that native peoples may be 'so low on the scale of social organization' that it is 'idle to impute to such people some shadow of the rights known to our law' can hardly be retained. If it were permissible in past centuries to keep the common law in step with international law, it is imperative in today's world that the common law should neither be nor be seen to be frozen in an age of racial discrimination.

"The fiction by which the rights and interests of indigenous inhabitants in land were treated as non-existent was justified by a policy which has no place in the contemporary law of this country....

"Whatever the justification in earlier days for refusing to recognize the rights and interests in land of the indigenous inhabitants of settled colonies, an unjust and discriminatory doctrine of that kind can no longer be accepted. The expectations of the international community accord in this respect with the contemporary values of the Australian people." ((1992) 107 ALR 1, 28-29).

201. See, for example, Alan Wertheimer, Exploitation (Princeton, N.J.: Princeton University Press, 1996) 252; Thomas Pogge, "Moral Universalism and Global Economic Justice" (2002) 1:1 Politics, Philosophy and Economics 29 at 50; Christopher Kutz, Complicity: Ethics and Law for a Collective Age (Cambridge and New York: Cambridge University Press, 2000).

202. Hannah Arendt, The Origins of Totalitarianism, $3^{\text {rd }}$ ed. (London: George Allen and Unwin, 1967) at 299.
Savitri Taylor, B.Com., LL.B.(Hons.) (Melb.), Ph.D. (Melb.), is a Senior Lecturer in the School of Law at La Trobe University and a member of the Committee of Management of the Refugee and Immigration Legal Centre Inc in Victoria. 